\title{
THE EFFECT OF WATER MAGNETIZED WITH NEGATIVE MAGNETIC FIELD ON EFFECTIVENESS OF SELECTED ZOOCIDES IN THE CONTROL OF TWO-SPOTTED SPIDER MITE (TETRANYCHUS URTICAE KOCH)
}

\author{
Romuald Górski ${ }^{*}$, Marek Wachowiak², Michał Tomczak ${ }^{1}$ \\ ${ }^{1}$ University of Life Sciences in Poznań, Department of Plant Protection Methods \\ Zgorzelecka 4, 60-198 Poznań, Poland \\ ${ }^{2}$ Institute of Plant Protection - National Research Institute \\ Władysława Węgorka 20, 60-318 Poznan, Poland
}

Received: January 5, 2008

Accepted: January 15, 2009

\begin{abstract}
The results of experiments showed an effect of negative magnetic field on some chemical and physical properties of water. A slight increase in iron (Fe) content, a decrease in zinc ( $\mathrm{Zn}$ ) level and an increase in surface tension (Dc) were observed in the study. At the same time the effect of magnetically modified water on an increase in effectiveness of tested zoocides was observed in the control of the two-spotted spider mite (Tetranychus urticae Koch). A strong and statistically significant increase in the effectiveness of zoocide Talstar 100 EC was recorded after the application of one and three magnetizers, preparation Omite $30 \mathrm{WP}$ after the application of two magnetizers, acaricide Magus 200 SC after the application of one and two magnetizers as well as a simultaneous use of one magnetizer and two semi-rings. Acaricide Ortus 05 SC showed a marked increase in the effectiveness in all treatments with the use of magnetically modified water.
\end{abstract}

Key words: magnetized water, effectiveness of zoocides, chemical control, Tetranychus urticae

\section{INTRODUCTION}

In chemical plant protection water is used as an extender of most applied plant protection agents. However, numerous compounds occurring under natural or artificial conditions affect physico-chemical properties of both water itself and the spray liquid containing assumed amounts of plant protection agents. These compounds may have a negative effect on biological effectiveness of plant protection agents in the control of pests. Such water properties include e.g. $\mathrm{pH}$, hardness (minerals dissolved in water, primarily calcium and magnesium salts) and suspended organic particles. In order to improve water quality different chemical compounds and substances as well as special water treatment facilities are used. Adjuvants are among agents applied for treatment of water used in plant protection measures. They are surfactants, modifying physico-chemical properties of spray liquid (Praczyk 2001; Woźnica et al. 2005). Magnetic activators, which are used as water treatment facilities, are successfully used in power, food, automobile industries and medicine (Szczypiorski et al. 2001; Kołecka 2005; Worsztynowicz 2005).

Magnetic field generated by a magnetizer causes the ordering and combining of conglomerates, i.e. clusters of water molecules, to form larger elements having an increased electric charge, trapping from the environment ionized molecules with an opposite charge. The action of a magnetizer results in a changed concentration of gases in water. The concentration of oxygen $\left(\mathrm{O}_{2}\right)$ increases while levels of carbon dioxide $\left(\mathrm{CO}_{2}\right)$, ozone $\left(\mathrm{O}_{3}\right)$ and chlorine $\left(\mathrm{Cl}_{2}\right)$ are reduced. It also turns out that after each water magnetization process iron $\left(\mathrm{Fe}^{2+}\right)$ content in water increases. As a result of the elevated oxygen bivalent this iron is oxidized to trivalent $\mathrm{Fe}^{3+}$. Thanks to this reaction iron hydroxide $\mathrm{Fe}(\mathrm{OH})_{3}$ is promptly precipitated. This results in a situation when iron compounds in magnetized water have a lesser effect on its total hardness. The action of the magnetic field also changes the electro-kinetic potential of water, its surface tension and viscosity and contributes to the stabilization of $\mathrm{pH}$. At present few studies are available on the application of magnetic activators in agriculture (Rochalska 2002; Podleśny et al. 2003; Kołecka 2005), especially in plant protection (Wachowiak and Kierzek 2002; Górski and Wachowiak 2004).

The aim of the study was to determine the effect of new generation magnetic activators ECOMAG, with negative polarity, modifying the properties of the spray liquid, on the effectiveness of selected zoocides in the control of the two-spotted spider mite (Tetranychus urticae Koch). Effectiveness of zoocides was evaluated after the application of water with different magnetization rates. 


\section{MATERIALS AND METHODS}

Experiments on the effect of water magnetized with a negative magnetic field on the effectiveness of selected zoocides in the control of the two-spotted spider mite (T. urticae) were conducted in 2006 and 2007 at the Department of Plant Protection Methods, the Poznań University of Life Sciences.

Tested plant protection agents were applied at minimum doses (Table 1). The minimum dose was considered to be such an amount of the preparation which killed approx. $50 \%$ specimens in the analyzed two-spotted spider mite population. The minimum dose was determined experimentally, by gradually reducing recommended doses.

Water for the experiments was taken from the water supply system, on which magnetic activators with a negative polarity ECOMAG by Akra (Warsaw, Poland) were installed in the following treatments: one, two, three magnetizers (each magnetizer consisting of a magnetic semi-ring with magnets mounted inside) or one magnetizer and additionally one ring made from the treatment of two magnetic semi-rings of single magnetizers. In the control treatment no magnetizers were applied and ordinary tap water was used to prepare spray liquid.

Experiments were conducted under laboratory conditions on plants of bean cv. Piękny Jaś cultivated in containers. Two-spotted spider mites were transferred onto plants at the two-leaf stage. Bean leaves with feeding pests, selected for testing, after several days were immersed for $3 \mathrm{~s}$ in a prepared solution of zoocides, containing magnetized water with different magnetization rates. Leaves covered with the preparation solution were placed onto glass plates lined with moistened filter paper. To provide accurate determination of the number of pests, plastic plates with openings of $3 \mathrm{~cm}$ in diameter were placed on leaf surface. Two-spotted red spider mite specimens were counted in the plate openings using a binocular. After counting was completed, plastic plates with openings were covered with glass plates so that the glass covered tightly all openings. The glass plate constituted a physical barrier preventing mite migration.

Each treatment was performed in five replications. Effectiveness of tested zoocides was determined using the Henderson-Tilton formula, based on the number of pest specimens found before and $24 \mathrm{~h}$ after treatment.

During the study physical parameters and $\mathrm{pH}$ of water used in the experiments were measured at the Department of Plant Protection Methods, the Poznań University of Life Sciences. Surface tension (Dc) of spray liquids was measured by tensiometry. Tested liquid was poured into a weighing bottle and placed on a pan of a tensiometer equipped with an electronic system for the replication of the assumed number of tests and display of results. After preliminary calibration of the device results were given in $\mathrm{mNm}^{-1}$. Measurements were taken at an identical temperature $\left(20^{\circ} \mathrm{C}\right)$ in 3 replications.

Table 1. Zoocides and their doses applied in the study

\begin{tabular}{|c|c|c|c|c|}
\hline No. & Name of zoocide & $\begin{array}{c}\text { Active substance } \\
\text { and its content in } \mathrm{g} / \mathrm{l}\end{array}$ & $\begin{array}{c}\text { recommended dose per one } \\
\text { litre of liquid }\end{array}$ & $\begin{array}{c}\text { Minimal dose applied per } \\
\text { one litre of liquid }\end{array}$ \\
\hline 1. & Magus 200 SC & Fenazaquin $-200 \mathrm{~g}$ & $0.06 \mathrm{ml}$ & $0.015 \mathrm{ml}$ \\
\hline 2. & Omite 30 WP & Propargite $-300 \mathrm{~g}$ & $1.00 \mathrm{~g}$ & $0.500 \mathrm{~g}$ \\
\hline 3. & Ortus 05 SC & Fenpyroximate $-50 \mathrm{~g}$ & $1.60 \mathrm{ml}$ & $0.400 \mathrm{ml}$ \\
\hline 4. & Talstar 100 EC & Bifenthrin $-100 \mathrm{~g}$ & $0.25 \mathrm{ml}$ & $0.125 \mathrm{ml}$ \\
\hline
\end{tabular}

Electrolytic conductivity (EC) was measured using conductometry with a CX 732 universal computer device type EPS - 2ZE by Eurosensor and a temperature probe. Readings were taken 3 min after sample preparation and results were presented for $25^{\circ} \mathrm{C}$. Measurements were taken in three replications and results were given in $\mathrm{mS}$.

Reaction was measured using a CX 732 universal computer device, coupled with a combination electrode by Hydromet and a temperature sensor. Results were referred to the temperature of $25^{\circ} \mathrm{C}$. Analyses of $\mathrm{pH}$ were performed in 5 replications, with 3 measurements being used in statistical analysis, and the minimum and maximum values were always rejected. Statistical analysis was performed on using the obtained results.

Results of $\mathrm{pH}$, electric conductivity (EC) and surface tension (Dc) were subjected to statistical analysis using $\mathrm{t}$-Student's test at the significance level $\mathrm{p}=0.05$.

A detailed chemical analysis of tested water treatments was performed at the Department of Horticultural Plant Nutrition, the Poznań University of Life Sciences in Poznań, in order to determine contents of macro- and microelements and water hardness. Results are presented in table 2.

\section{RESULTS AND DISCUSSION}

As it was reported by Chibowski et al. (2003), magnetic activation of water may result in changes in its chemical properties. Also in this study chemical analysis of tested treatment of water with different magnetization rates showed the effect of magnetic field on selected chemical properties of water (Table 2). A slight increase in iron $(\mathrm{Fe})$ and a decrease in zinc ( $\mathrm{Zn})$ contents were recorded. A higher iron concentration in water subjected to magnetic activation was also reported by Szczypiorowski et al. (2001).

Reactions taking place in magnetized water may affect chemical processes occurring in spray liquid containing different plant protection agents. Chemical composition of the plant protection agent and contents of adjuvants included in its formulation may be modified by treated water and as a consequence influence biological effectiveness of the preparation in pest control. Moreover, the time between the preparation of spray liquid and its application, as well as meteorological conditions may also have a multisided effect on chemical processes taking place in the sprayer tank. 
Table 2. Effect of water magnetization on its chemical and physical properties

\begin{tabular}{|c|c|c|c|c|c|c|}
\hline & \multirow[b]{2}{*}{ No. } & \multicolumn{5}{|c|}{ Experimental object } \\
\hline & & one magnetizer & two magnetizers & three magnetizers & $\begin{array}{l}\text { one magnetizer and } \\
\text { two semi-rings }\end{array}$ & control \\
\hline \multicolumn{7}{|c|}{ Macro- and microelements in $\mathrm{mg} / \mathrm{l}$} \\
\hline 1. & $\mathrm{~N}-\mathrm{NO}_{3}$ & trace element & trace element & trace element & trace element & trace element \\
\hline 2. & $\mathrm{~N}-\mathrm{NH}_{4}$ & 0.300 & trace element & trace element & 0.300 & 0.300 \\
\hline 3. & $\mathrm{P}-\mathrm{PO}_{4}$ & 0.700 & 0.700 & 0.700 & 0.700 & 0.700 \\
\hline 4. & $\mathrm{~K}$ & 4.400 & 4.300 & 4.300 & 4.300 & 4.400 \\
\hline 5. & $\mathrm{Ca}$ & 67.800 & 70.300 & 68.000 & 66.400 & 69.700 \\
\hline 6. & $\mathrm{Mg}$ & 18.200 & 18.700 & 18.400 & 18.300 & 18.800 \\
\hline 7. & $\mathrm{Na}$ & 26.000 & 26.000 & 25.800 & 26.000 & 26.100 \\
\hline 8. & $\mathrm{Cl}$ & 31.500 & 31.700 & 31.400 & 30.900 & 31.900 \\
\hline 9. & $\mathrm{~S}_{-} \mathrm{SO}_{4}$ & 52.100 & 51.900 & 52.000 & 51.300 & 52.300 \\
\hline 10. & $\mathrm{Fe}$ & 0.009 & 0.023 & 0.030 & 0.033 & 0.014 \\
\hline 11. & $\mathrm{Mn}$ & 0.019 & 0.015 & 0.022 & 0.019 & 0.016 \\
\hline 12. & $\mathrm{Zn}$ & 0.015 & 0.014 & 0.011 & 0.011 & 0.020 \\
\hline 13. & $\mathrm{~B}$ & 0.012 & 0.011 & 0.013 & 0.012 & 0.011 \\
\hline 14. & $\mathrm{Cu}$ & trace element & trace element & trace element & trace element & trace element \\
\hline 15. & $\mathrm{HCO}_{3}$ & 231.200 & 235.500 & 229.900 & 230.600 & 233.600 \\
\hline \multicolumn{7}{|c|}{ Hardness in ${ }^{\circ} \mathrm{dH}$} \\
\hline 16. & Hardness Ca & 9.500 & 9.800 & 9.500 & 9.300 & 9.800 \\
\hline 17. & Hardness Mg & 4.200 & 4.300 & 4.300 & 4.200 & 4.400 \\
\hline 18. & $\mathrm{pH}$ & $7.3900 \mathrm{a}$ & $7.4000 \mathrm{a}$ & $7.4100 \mathrm{a}$ & $7.4100 \mathrm{a}$ & $7.3900 \mathrm{a}$ \\
\hline \multicolumn{7}{|c|}{ Physical properties } \\
\hline 19. & $\mathrm{EC}^{*}$ & $0.5910 \mathrm{a}$ & $0.5920 \mathrm{a}$ & $0.5916 \mathrm{a}$ & $0.5907 \mathrm{a}$ & $0.5944 \mathrm{a}$ \\
\hline 20. & $\mathrm{Dc}^{* *}$ & $72.5600 \mathrm{ab}$ & $72.4100 \mathrm{a}$ & $72.8500 \mathrm{~b}$ & $73.3700 \mathrm{c}$ & $72.3000 \mathrm{a}$ \\
\hline
\end{tabular}

* EC - electric conductivity $(\mathrm{mS})$

** Dc - surface tension $\left(\mathrm{mNm}^{-1}\right)$

Mean values marked with the same letter do not differ at the significance level $p=0.05$ according to t-Student's test

Table 3. Effect of magnetized water on the effectiveness of zoocides in the control of two-spotted spider mite (Tetranychus urticae Koch)

\begin{tabular}{|c|c|c|c|c|c|}
\hline \multirow{2}{*}{ No. } & \multirow{2}{*}{ Experimental object } & \multicolumn{3}{|c|}{ Mean effectiveness of zoocides in percentage } \\
\cline { 3 - 5 } & & Talstar 100 EC & Omite 30 WP & Magus 200 SC & Ortus 05 SC \\
\hline 1. & One magnetizer & $68.96 \mathrm{c}$ & $58.16 \mathrm{ab}$ & $82.36 \mathrm{bc}$ & $76.26 \mathrm{~b}$ \\
\hline 2. & Two magnetizers & $51.83 \mathrm{~b}$ & $71.80 \mathrm{~b}$ & $76.60 \mathrm{~b}$ & $87.20 \mathrm{bc}$ \\
\hline 3. & Three magnetizers & $65.06 \mathrm{c}$ & $58.43 \mathrm{ab}$ & $58.36 \mathrm{ab}$ & $85.13 \mathrm{bc}$ \\
\hline 4. & One magnetizer and two semi-rings & $54.40 \mathrm{~b}$ & $59.56 \mathrm{ab}$ & $83.80 \mathrm{c}$ & $97.46 \mathrm{c}$ \\
\hline 5. & Control & $41.63 \mathrm{a}$ & $43.56 \mathrm{a}$ & $46.30 \mathrm{a}$ & $55.26 \mathrm{a}$ \\
\hline
\end{tabular}

Mean values marked with the same letter do not differ at the significance level $p=0.05$ according to $t$-Student's test

No significant effect of magnetic field on changes in water $\mathrm{pH}$ and electrolytic conductivity (EC) was found in the conducted experiments. In contrast, magnetic treatment of water was observed to influence the value of surface tension (Dc). The biggest and at the same time statistically significant increase of surface tension was observed in the treatment with strongly magnetized water, i.e. that magnetized with one magnetizer and additionally two semi-rings. A significant increase in surface tension was also found in the treatment with three magnetizers. In agricultural practice increased surface tension of spray liquid used in plant protection is not desirable and - depending on the used spraying equipment - it most frequently leads to the deteriorated coverage of plant surfaces with spray liquid (Wachowiak and Kierzek 2003).
Results presented in table 3 indicate an effect of magnetized water used to dilute plant protection agents on their effectiveness. After the application of water magnetized using magnetic activators by ECOMAG generating a negative field, the efficiency of all tested zoocides in the control of two-spotted spider mite (T. urticae) was found to increase. A strong and at the same time statistically significant increase was observed for the effectiveness of zoocide Talstar 100 EC after the application of one and three magnetizers, Omite 30 WP after the application of two magnetizers, acaricide Magus 200 SC after the application of one and two magnetizers, and one magnetizer together with two semi-rings. Acaricide Ortus 05 SC showed a marked increase in the effectiveness for all treatments with the use of magnetically modified water. 
In the conducted experiments a higher effectiveness was found for tested plant protection agents in the control of the two-spotted spider mite in comparison to earlier results reported by Górski and Wachowiak (2004). It should to be mentioned here that Górski and Wachowiak (2004) in their experiments applied identical preparations as it was done in the present study. Differences in results may be a consequence of a different polarity of applied magnetizers.

The effect of magnetized water used to prepare spray liquid on the effectiveness of plant protection agents was also observed by Wachowiak and Kierzek (2002). These authors reported an increased effectiveness of selected fungicides in the control of phytophthora fungus [Phytophtora infestans (Mont.) de Bary] found on potato, after the application of these fungicides diluted in water subjected to the action of a magnetic field generated by a MULTIMAG magnetic activator.

\section{CONCLUSIONS}

1. Magnetization of water with a strong magnetic field with a negative polarity using ECOMAG magnetizers did not cause significant changes in the chemical composition of water. Slight changes were only observed in contents of iron $(\mathrm{Fe})$ and zinc $(\mathrm{Zn})$.

2. Magnetic modification of water did not cause changes in its $\mathrm{pH}$ and electrolytic conductivity (EC). However, it resulted in a slight increase in surface tension (Dc).

3. A negative magnetic field generated by an ECOMAG magnetic activator had an advantageous effect on the effectiveness of plant protection agents. It was found that water subjected to magnetic modification resulted in an increased effectiveness of zoocides: Magus 200 SC; Omite 30 WP; Ortus 05 SC and Talstar $100 \mathrm{EC}$ in the control of the two-spotted spider mite (T. urticae).

\section{REFERENCES}

Chibowski E., Hotysz L., Szcześ A. 2003. Time dependent changes in zeta potential of freshly precipitated calcium carbonate. Colloids and Surfaces A: Physicochem. Eng. Aspects 222: 41-54.

Górski R., Wachowiak M. 2004. Effect of magnetized water on the effectiveness of selected zoocides in the control of red spider mite (Tetranychus urticae Koch) and grain weevil (Sitophilus granarius L.). J. Plant Protection Res. 44 (1): 13-19.

Kołecka K. 2005. Wpływ magnetyzerów na właściwości wody oraz możliwości ich zastosowania. Gaz, Woda i Technika Sanitarna 2: 17-20.

Podleśny J., Lenartowicz W., Sowiński M. 2003. Wpływ biostymulacji magnetycznej nasion na kształtowanie cech morfologicznych i plonowanie łubinu białego. Zesz. Probl. Post. Nauk Rol. 495: 399-406.

Praczyk T. 2001. Rozwój badań i zastosowań adiuwantów w Polsce. Prog. Plant Protection/Post. Ochr. Roślin 41 (1): 110-113.

Rochalska M. 2002. Pole magnetyczne jako środek poprawy wigoru nasion. Acta Agrophysica 62: 103-111.
Szczypiorski A., Witaszak K., Rzepliński A. 2001. Aktywatory magnetyczne nowej generacji - Multimag - Ecomag - do wody i ścieków. Gospodarka Paliwami i Energią 4: 26-27.

Wachowiak M., Kierzek R. 2002. Uzdatnianie wody stosowanej do sporządzania cieczy użytkowej jako element poprawy efektywności zabiegów. Prog. Plant Protection/Post. Ochr. Roślin 42 (2): 490-493.

Wachowiak M., Kierzek R. 2003. Wpływ dawki środka ochrony roślin, dodatku adiuwanta i wielkości kropel na efektywność zwalczania agrofagów. Prog. Plant Protection/Post. Ochr.Roślin 43 (2): 994-997.

Worsztynowicz B. 2005. Analiza jakościowa spalanej aktywowanej magnetycznie mieszanki. Mechanics 24 (3): 227-229.

Woźnica Z., Adamczewski K., Heller K. 2005. Adiuwanty do środków ochrony roślin - aktualne trendy badawcze. Prog. Plant Protection/Post. Ochr. Roślin 45 (1): 524-532.

\section{POLISH SUMMARY}

WPŁYW NAMAGNETYZOWANEJ WODY
UJEMNYM POLEM MAGNETYCZNYM NA
SKUTECZNOŚĆ DZIAŁANIA WYBRANYCH
ZOOCYDÓW W ZWALCZANIU PRZĘDZIORKA
CHMIELOWCA (TETRANYCHUS URTICAE KOCH)

Badania nad wpływem wody namagnetyzowanej ujemnym polem magnetycznym na skuteczność działania wybranych zoocydów w zwalczaniu przędziorka chmielowca (Tetranychus urticae Koch) przeprowadzono w latach 2006 i 2007, w Katedrze Metod Ochrony Roślin Uniwersytetu Przyrodniczego w Poznaniu.

Testowane środki ochrony roślin stosowano $\mathrm{w}$ dawkach minimalnych. Za dawkę minimalną uznano taką ilość preparatu, która spowodowała śmiertelność około $50 \%$ osobników badanej populacji przędziorka chmielowca. Dawkę minimalną wyznaczono doświadczalnie, stopniowo obniżając dawki zalecane. Do doświadczeń stosowano wodę pobieraną z instalacji wodociagowej, na której zamontowano aktywatory magnetyczne o ujemnej biegunowości, typu ECOMAG firmy "Akra” z Warszawy, w kombinacjach: jeden, dwa, trzy magnetyzery (każdy magnetyzer zbudowany jest z półpierścienia magnetycznego z umieszczonymi wewnątrz magnesami) lub jeden magnetyzer i dodatkowo pierścień powstały z połączenia dwóch półpierścieni magnetycznych pojedynczych magnetyzerów. W kombinacji kontrolnej nie stosowano magnetyzerów, a do sporządzania cieczy użytkowej używano zwykłej wody wodociągowej.

Wybrane do testów liście fasoli odmiany „Piękny Jaś” z żerującym przędziorkiem chmielowcem zanurzano na 3 sekundy w przygotowanym roztworze środka ochrony roślin rozcieńczonego $\mathrm{w}$ wodzie poddanej aktywacji magnetycznej, a następnie umieszczono je na szklanych płytkach wyłożonych zwilżoną bibułą filtracyjną. Śmiertelność szkodnika określono po upływie 24 godzin od momentu naniesienia preparatu.

Przeprowadzona analiza wody o różnym stopniu namagnetyzowania wykazała wpływ pola magnetycznego na jej niektóre właściwości chemiczne i fizyczne. 
Zauważono bowiem niewielki wzrost zawartości żelaza (Fe), spadek ilości cynku ( $\mathrm{Zn}$ ) oraz wzrost napięcia powierzchniowego (Dc).

W prowadzonych badaniach stwierdzono wpływ wody poddanej modyfikacji magnetycznej na wzrost skuteczności działania testowanych zoocydów w zwalczaniu przędziorka chmielowca (T. urticae). Silny i zarazem statystycznie istotny wzrost efektywności zoocydu Talstar
100 EC zanotowano po zastosowaniu jednego i trzech magnetyzerów, preparatu Omite $30 \mathrm{WP}$ po użyciu dwóch magnetyzerów, akarycydu Magus 200 SC po zastosowaniu jednego i dwóch magnetyzerów oraz jednego magnetyzera i jednocześnie dwóch półpierścieni. Preparat Ortus 050 SC wykazywał zdecydowany wzrost skuteczności działania we wszystkich kombinacjach z zastosowaniem wody poddanej modyfikacji magnetycznej. 
